\title{
Pengaruh Pendidikan Kesehatan dengan Media Booklet Terhadap Pengetahuan, Sikap dan Tindakan Ibu Tentang Stimulasi Perkembangan Anak Usia Pra Sekolah di Wilayah Kerja Puskesmas Lubuk Buaya Kota Padang
}

\author{
Melda Saputri*, Eva Chundrayetti, Deswita \\ Program Studi Pasca Sarjana Keperawatan Universitas Andalas, Bagian Keilmuan Keperawatan Anak, \\ Fakultas Keperawatan, Universitas Andalas \\ *Correspondence email: meldasaputri11@gmail.com
}

\begin{abstract}
Abstrak. Anak merupakan generasi penerus bangsa, sehingga dibutuhkan anak dengan kualitas baik agar tercapai masa depan bangsa yang berkualitas. Kenyataannya di negara berpenghasilan rendah dan menengah tidak dapat mewujudkan potensi pengembangan penuh terhadap anak. Diperlukan stimulasi yang sesuai seperti dengan media booklet agar anak berkembang dengan baik. Penelitian ini penelitian kuantitatif menggunakan desain "Pre and Post test Control Group yang bertujuan melihat pengaruh pendidikan kesehatan dengan media booklet terhadap pengetahuan, sikap dan tindakan tentang stimulasi perkembangan anak prasekolah di wilayah kerja Puskesmas Lubuk Buaya Kota Padang.Populasiberjumlah 959. Sampel berjumlah 34 responden, 17 responden kelompok intervensi dan 17 kelompok kontrol. Ada pengaruh pendidikan kesehatan terhadap pengetahuan $(\mathrm{p}=0,002)$, sikap $(\mathrm{p}=0,004)$ dan tindakan $(\mathrm{p}=0,006)$ pada kelompok intervensi. Tidak ada pengaruh pendidikan kesehatan terhadap pengetahuan $(\mathrm{p}=0,163)$, sikap $(\mathrm{p}=0,083)$ dan tindakan $(\mathrm{p}=0,183)$ pada kelompok kontrol. Diharapkan perawat yang ada di masyarakat mengedukasi ibu mengenai stimulasi perkembangan anak dan diharapkan ibu mau menyediakan waktunya untuk membaca booklet, melaksanakan segala bentuk stimulasi pada anak sesuai dengan yang tercantum pada booklet.
\end{abstract}

Kata kunci: Pendidikan Kesehatan; Booklet; Pengetahuan; Sikap; Tindakan; Stimulasi Perkembangan Anak

Abstract. Children are the next generation of the nation, so it takes children with good quality in order to achieve a quality future of the nation. The reality is that low and middle income countries cannot realize the full development potential of children. Appropriate stimulation is needed such as with booklet media so that children develop well. This research is a quantitative study using the "Pre and Post test Control Group" design which aims to see the effect of health education with booklet media on knowledge, attitudes and actions about stimulating the development of preschool children in the work area of the Lubuk Buaya Health Center, Padang City. The population is 959. The sample is 34 respondents, 17 respondents in the intervention group and 17 in the control group. There was an effect of health education on knowledge $(p=0.002)$, attitude $(p=0.004)$ and action $(p=0.006)$ in the intervention group. There was no effect of health education on knowledge $(p=0.163)$, attitudes $(p=0.083)$ and actions $(p=0.183)$ in the control group. It is hoped that nurses in the community educate mothers about stimulating child development and it is hoped that mothers will take the time to read booklets, carry out all forms of stimulation to children according to what is listed in the booklet.

Keywords: Health Education; Booklet; Knowledge; Attitude; Action; Stimulation of Child Development

\section{PENDAHULUAN}

Anak merupakan generasi penerus bangsa, sehingga dibutuhkan anak dengan kualitas yang baik agar tercapai masa depan bangsa yang berkualitas, anak yang baik harus dipastikan bahwa tumbuh kembanngnya juga baik. Proses tumbuh kembang anak dapat berlangsung secara ilmiah, tetapi proses tersebut sangat tergantung kepada orang tua (Putra et al., 2018).

Perkembangan adalah bertambahnya kemampuan struktur dan fungsi tubuh yang lebih komplek, dalam pola yang teratur dan dapat diramalkan dari hasil pematangan/maturase. Perkembangan menyangkut proses diferensiasi sel, jaringan tubuh, organ dan sistem organ yang berkembang sedemikian rupa sehingga masing-masing dapat memenuhi fungsinya. Termasuk juga perkembangan kognitif, bahasa, motorik, emosi dan perkembangan perilaku sebagai hasil dari ineteraksi dengan lingkungannya (Soetjiningsih, 2017).

Stimulasi adalah perangsangan yang datang dari lingkungan luar anak. Anak yang mendapatkan stimulasi yang terarah dan teratur akan lebih cepat berkembang dibanding dengan anak yang kurang baik/tidak mendapatkan stimulasi. Stimulasi dapat diberikan oleh orang-orang yang berada di sekitar lingkungan anak. Mulai dari guru, pengasuh, keluarga serta orang yang paling dekat dengan anak yaitu orang tua (Soetjiningsih, 2017).

UNICEF (2017) menunjukkan lebih dari sepertiga balita di negara-negara berkembang mengalami masalah pertumbuhan dan perkembangan yang tidak sesuai dengan usianya. Hal ini disebakan oleh beberapa faktor antara lain kemiskinan, gizi buruk dan lingkungan yang tidak responsif dalam menstimulasi proses 
Melda Saputri et al., Pengaruh Pendidikan Kesehatan dengan Media Booklet Terhadap Pengetahuan, Sikap dan Tindakan Ibu Tentang Stimulasi Perkembangan Anak Usia Pra Sekolah di Wilayah Kerja Puskesmas Lubuk Buaya Kota Padang

perkembangan anak (Kusuma, 2013). Selain itu, penelitian terkait faktor-faktor penyebab keterlambatan perkembangan pada anak menunjukkan sekitar $80 \%$ penyebab keterlambatan perkembangan anak adalah karena kurangnya stimulasi (Fadlyana et al, 2016).

Data Kemenkes RI dalam profil kesehatan Indonesia tahun 2016, mengemukakan bahwa sebanyak $56,4 \%$ anak yang berusia di bawah lima tahun menderita gangguan tumbuh kembang (Syahailatua \& Kartini, 2020). Indikator keberhasilan program Deteksi Dini Tumbuh Kembang balita yang ditetapkan oleh Kementrian Kesehatan RI tahun 2017 adalah 90\% dari total populasi, sementara hasil Stimulasi Deteksi Dini Tumbuh Kembang balita di Propinsi Sumatra Barat tahun 2017 adalah 53,14\% (Syofiah et al., 2019).

Data dari Dinas Kesehatan Kota Padang tahun 2020 mengenai pelayanan stimulasi deteksi dini tumbuh kembang dari $85 \%$ pada tahun 2019 menjadi 50,36\%, dari 23 Puskesmas di dapatkan data gannguan perkembangan pada anak balita sebanyak 87 orang anak (perkembangan motorik kasar: 29 orang, motorik halus: 21 orang, bicara bahasa: 35 orang dan sosialisasi kemandirian: 8 orang), meliputi Puskesmas Lubuk Buaya (17 balita mengalami gangguan perkembangan dan yang mendapatkan pelayanan sitmulasi sebanyak $(78,63 \%)$ (Dinkes, 2020). Puskesmas Lubuk Buaya adalah cakupan stimulasi deteksi dini tumbuh kembangnya belum mencapai target yaitu $63,2 \%$.

Kurangnya pengetahuan, sikap dan keterampilan orang tua sangat berdampak dalam pemenuhan kebutuhan akan stimulasi pada anak. Belum optimalnya stimulasi perkembangan yang diberikan kepada anak sangat berdampak terhadap tingkat perkembangan anak. Mengingat masih rendahnya pengetahuan dan sikap ibu mengenai stimulasi, maka diperlukan upaya peningkatan pengetahuan dan sikap melalui Pendidikan kesehatan yang memungkinkan ibu mendapatkan pembelajaran mengenai stimulasi perkembangan. Pendidikan kesehatan yaitu serangkaian upaya yang ditujukan untuk menggugah kesadaran, memberikan dan meningkatkan pengetahuan sasaran pendidikan kesehatan yang menyangkut tentang pemeliharaan kesehatan dan peningkatan kesehatan untuk individu, kelompok, keluarga serta masyarakat (Yopy et al., 2014).

Pendidikan kesehatan merupakan disiplin ilmu dengan serangkaian kompetensi yang berbasis keterampilan, melibatkan masyarakat terutama ibu (Azwar, 2013). Hal ini menjadi alasan peneliti untuk melakukan penelitian mengenai pengaruh Pendidikan kesehatan dengan media terhadap pengetahuan, sikap dan Tindakan ibu tentang stimulasi perkembangananak usia pra-sekolah. Penelitian tentang pengaruh pendidikan kesehatan dengan media booklet terhadap pengetahuan, sikap dan tindakan ibu tentang stimulasi perkembangan anak prasekolah di wilayah kerja Puskesmas Lubuk Buaya penting dilakukan karena belum pernah dilakukan mengingat masih dijumpainya kejadian keterlambatan perkembangan di wilayah tersebut.

\section{METODE}

Penelitian ini merupakan penelitian kuantitatif menggunakan desain penelitian "Quasy Experimental Pre-Post Test With Control Group. Waktu penelitian ini dilaksanakan dalam 4 tahap antara lain penyusunan proposal, pengumpulan data dan penyusunan hasil penelitian yang dimulai dari Bulan April sampai dengan Juli 2021. Populasi dalam penelitian adalah semua ibu yang memiliki anak Prasekolah di Kelurahan Lubuk Buaya wilayah kerja Puskesmas Lubuk Buaya Padang pada tahun 2020 dengan jumlah populasi sebanyak 959 orang. Sampel sebanyak 34 sampel yang terdiri dari 17 kelompok intervensi dan 17 kelompok kontrol. teknik pengambilan sampel proportional random sampling. Analisis data yang digunakan adalah univariat dan bivariat.

\section{HASIL DAN PEMBAHASAN}

Tabel 1. Gambaran Karakteristik Keluarga di Wilayah Kerja Puskesmas Sei Duren Jambi

\begin{tabular}{|c|c|c|c|c|c|}
\hline \multirow[t]{2}{*}{ No } & \multirow[t]{2}{*}{ Karakteristik } & \multicolumn{2}{|c|}{$\begin{array}{l}\text { Kelompok } \\
\text { Intervensi }\end{array}$} & \multicolumn{2}{|c|}{$\begin{array}{c}\text { Kelompok } \\
\text { Kontrol }\end{array}$} \\
\hline & & f & $\%$ & $\mathbf{f}$ & $\%$ \\
\hline \multirow[t]{3}{*}{1} & Usia & & & & \\
\hline & $>40$ Tahun & 4 & 23.5 & 5 & 29.4 \\
\hline & $18-40$ Tahun & 13 & 76.5 & 12 & 70.6 \\
\hline \multirow[t]{3}{*}{2} & Pendidikan & & & & \\
\hline & SMA & 15 & 88.2 & 14 & 82.4 \\
\hline & Perguruan Tinggi & 2 & 11.8 & 3 & 17.6 \\
\hline \multirow[t]{4}{*}{3} & Pekerjaan Ibu & & & & \\
\hline & PNS & 2 & 11.8 & 3 & 17.6 \\
\hline & Wiraswasta & 13 & 76.5 & 11 & 64.7 \\
\hline & IRT/Tidak Bekerja & 2 & 11.8 & 3 & 17.6 \\
\hline \multirow[t]{5}{*}{4} & Jumlah Anak & & & & \\
\hline & 1 Orang & 1 & 5.9 & 1 & 5.9 \\
\hline & 2 Orang & 14 & 82.4 & 14 & 82.4 \\
\hline & 3 Orang & 1 & 5.9 & 1 & 5.9 \\
\hline & 4 Orang & 1 & 5.9 & 1 & 5.9 \\
\hline \multirow[t]{4}{*}{5} & Usia Anak & & & & \\
\hline & 3-4 Tahun & 6 & 35.3 & 5 & 29.4 \\
\hline & 4-5 Tahun & 8 & 47.1 & 9 & 52.9 \\
\hline & 5-6 Tahun & 3 & 17.6 & 3 & 17.6 \\
\hline
\end{tabular}

Berdasarkan tabel 1 diketahui distribusi frekuensi karakteristik kelompok intervensi adalah sebagian besar responden berumur 18-40 tahun $(70,6 \%)$, berpendidikan SMA $(82,4 \%)$, pekerjaan wiraswasta $(64,7 \%)$, jumlah anak 2 orang $(82,4 \%)$ dan usia anak 4-5 tahun $(47,1 \%)$. Selanjutnya distribusi frekuensi karakteristik kelompok kontrol adalah sebagian besar responden berumur 18-40 tahun $(76,5 \%)$, berpendidikan SMA $(88,2 \%)$, pekerjaan wiraswasta $(76,5 \%)$, jumlah anak 2 orang $(82,4 \%)$, anak ke $2(76,5 \%)$ dan usia anak 4-5 tahun $(52,9 \%)$. 
Melda Saputri et al., Pengaruh Pendidikan Kesehatan dengan Media Booklet Terhadap Pengetahuan, Sikap dan Tindakan Ibu Tentang Stimulasi Perkembangan Anak Usia Pra Sekolah di Wilayah Kerja Puskesmas Lubuk Buaya Kota Padang

Tabel 2. Distribusi Rerata Tingkat Pengetahuan, Sikapdan Tindakan Ibu Tentang Stimulasi Perkembangan Anak Usia Prasekolah Sebelum dan Sesudah Dilakukan Pendidikan Kesehatan dengan Media Booklet $(\mathrm{n}=17)$

\begin{tabular}{llcccc}
\hline \multirow{2}{*}{ No } & Rata-rata & \multicolumn{2}{c}{$\begin{array}{c}\text { Kelompok } \\
\text { Intervensi }\end{array}$} & & \multicolumn{2}{c}{ Kelompok Kontrol } \\
\cline { 3 - 6 } & & Mean & Min-Max & Mean & Min-Max \\
\hline $\mathbf{1}$ & $\begin{array}{l}\text { Pengetahuan } \\
\text { a. Pre Test }\end{array}$ & 7.12 & $5-9$ & 7.00 & $5-9$ \\
\multirow{2}{*}{$\mathbf{2}$} & $\begin{array}{l}\text { b. Post Test } \\
\text { Sikap }\end{array}$ & 13,76 & $12-15$ & 7.12 & $5-9$ \\
& \begin{tabular}{l} 
a. Pre Test \\
\multirow{2}{*}{3}
\end{tabular} & 28.06 & $25-31$ & 27.94 & $25-31$ \\
& $\begin{array}{l}\text { b. Post Test } \\
\text { Tindakan }\end{array}$ & 45.59 & $43-48$ & 28.12 & $25-31$ \\
& $\begin{array}{l}\text { a. Pre Test } \\
\text { b. Post Test }\end{array}$ & 14.35 & $13-16$ & 14.29 & $13-16$ \\
\hline
\end{tabular}

Berdasarkan tabel 2 diketahui bahwa untuk kelompok intervensi, rata-rata pre test pengetahuan tentang stimulasi perkembangan anak usia prasekolahadalah 7,12. Sedangkan rata-rata pada post test pengetahuan adalah 13,76. Selanjutnya untuk kelompok kontrol rata-rata pre test pengetahuan adalah 7,00. Sedangkan rata-rata pada post test adalah 7,12. Berdasarkan hal tersebut maka dapat disimpulkan bahwa pengetahuan tentang stimulasi perkembangan anak usia prasekolah pada kelompok intervensi lebih tinggi peningkatannya dibandingkan dengan kelompok kontrol.

Kemudian rata-rata pre test sikap tentang stimulasi perkembangan anak usia prasekolah kelompok intervensi adalah 28,06. Sedangkan rata-rata pada post test sikap adalah 45,59. Selanjutnyauntuk kelompok kontrol rata-rata pre tes tsikap adalah 27,94 . Sedangkan rata-rata pada post test sikap adalah 28,12. Berdasarkan hal tersebut maka dapat disimpulkan bahwa sikap tentang stimulasi perkembangan anak usia prasekolah pada kelompok intervensi lebih tinggi peningkatannya dibandingkan dengan kelompok kontrol.

Selanjutnya rata-rata pre test tindakan tentang stimulasi perkembangan anak usia prasekolah kelompok intervensi adalah 14,35. Sedangkan rata-rata pada post test tindakan adalah 22,59. Selanjutnya untuk kelompok kontrol rata-rata pre test tindakan adalah 14,29. Sedangkan rata-rata pada post test tindakan adalah 14,41. Berdasarkan hal tersebut maka dapat disimpulkan bahwa tindakan tentang stimulasi perkembangan anak usia prasekolah pada kelompok intervensi lebih tinggi peningkatannya dibandingkan dengan kelompok kontrol.
Tabel 3. Pengaruh Pendidikan Kesehatan terhadap Pengetahuan, Sikap dan Tindakan Ibu Tentang Stimulasi Perkembangan Anak Usia Prasekolah pada Kelompok Intervensi dan Kelompok Kontrol $(n=17)$

\begin{tabular}{|c|c|c|c|c|}
\hline No & Kelompok & Mean & $\mathbf{n}$ & P value \\
\hline \multirow[t]{9}{*}{1} & Kelompok Intervensi & & \multirow{5}{*}{17} & \multirow{5}{*}{0.002} \\
\hline & a. Pengetahuan & & & \\
\hline & Pre Test & 7.12 & & \\
\hline & Post Test & 13,76 & & \\
\hline & b. Sikap & & & \\
\hline & Pre Test & 28.06 & \multirow{2}{*}{17} & \multirow{2}{*}{0.004} \\
\hline & Post Test & 45.59 & & \\
\hline & $\begin{array}{l}\text { c. Tindakan } \\
\text { Pre Test }\end{array}$ & 14.35 & \multirow[b]{2}{*}{17} & \multirow[b]{2}{*}{0.006} \\
\hline & Post Test & 22.59 & & \\
\hline \multirow[t]{7}{*}{2} & $\begin{array}{l}\text { Kelompok Kontrol } \\
\text { a. Pengetahuan }\end{array}$ & & & \\
\hline & Pre Test & 7.00 & \multirow[t]{2}{*}{17} & \multirow[t]{2}{*}{0.163} \\
\hline & b. Pengetahuan & & & \\
\hline & Pre Test & 27.94 & \multirow{2}{*}{17} & \multirow{2}{*}{0.083} \\
\hline & $\begin{array}{ll}\text { Post Test } \\
\text { c. } & \text { Tindakan }\end{array}$ & 28.12 & & \\
\hline & Pre Test & 14.29 & \multirow{2}{*}{17} & \multirow{2}{*}{0.183} \\
\hline & Post Test & 14.41 & & \\
\hline
\end{tabular}

Berdasarkan tabel 3 tentang pengaruh pendidikan kesehatan terhadap pengetahuan, sikap dan tindakan tentang stimulasi perkembangan anak usia prasekolah pada kelompok intervensi dan kelompok kontrol dengan menggunakan uji statistik paired samplet-test (TDependen) Hasil pada kelompok intervensi tentang pengetahuan didapati $\mathrm{p}$ value 0,002 , sikap didapati $\mathrm{p}$ value 0,004 , tindakan didapati $\mathrm{p}$ value 0,006 . Hal ini berarti bahwa pada kelompok intervensi ada pengaruh yang signifikan dari pendidikan kesehatan terhadap pengetahuan, sikap dan tindakan tentang stimulasi perkembangan anak usia prasekolah di wilayah kerja Puskesmas Lubuk Buaya Padang.

Selanjutnya berdasarkan tabel di atas juga diketahui hasil pada kelompok kontrol tentang pengetahuan tentang stimulasi perkembangan anak usia prasekolah didapati $\mathrm{p}$ value 0,163 , sikap didapati $\mathrm{p}$ value 0,083 , tindakan didapati $\mathrm{p}$ value 0,183 . Hal ini berarti bahwa pada kelompok kontrol tidak ada pengaruh yang signifikan dari pendidikan kesehatan terhadap pengetahuan, sikap dan tindakan tentang stimulasi perkembangan anak usia prasekolah di wilayah kerja Puskesmas Lubuk Buaya Padang.

\section{Pembahasan \\ Rerata Tingkat Pengetahuan, Sikap dan Tindakan Ibu Tentang Stimulasi Perkembangan Anak Usia Prasekolah Sebelum dan Sesudah Dilakukan Pendidikan Kesehatan dengan Media Booklet} Pengetahuan

Berdasarkan hasil penelitian yang sudah dilakukan peneliti tentang rata-rata pengetahuan sebelum dan setelah diberikan intervensi (pada kelompok intervensi dan kelompok kontrol) didapati 
hasil rata-rata pre test pengetahuan kelompok intervensi adalah $7,12(47,4 \%)$ (dari total skor 15$)$. Selanjutnya rata-rata pre test pengetahuan kelompok kontrol adalah $7,00(46,6 \%)$ (dari total skor 15). Hasil penelitian ini menunjukkan bahwa rata-rata pre test pengetahuan kedua kelompok perlu ditingkatkan.

Hasil penelitan ini sejalan dengan penelitian Antriana \& Suyanti (2019)menyatakan bahwa nilai ratarata pre test pengetahuan responden masih rendah yakni $59,17(49,30 \%$ ) (dari total skor 120). Selanjutnya penelitian Cumayunaro (2020) juga menemukan bahwa rata-rata pre test pengetahuan yang rendah $(12,55)$ $(44,82 \%)$ (dari total skor 28). Kemudian Latifah \& Andriani (2018) juga menemukan hasil bahwa skor pre test pengetahuan ibu masih rendah yaitu 52,91 (47,36\%) (dari total skor 110).

Setelah diberikan pendidikan kesehatan degan media booklet (post test), rata-rata pengetahuan ibu tentang stimulasi perkembangan anak usia prasekolah pada kelompok intervensi telah mengalami peningkatan, yakni dari $7,12(47,4 \%)$ menjadi $13,76(91,73 \%)$ (ratarata meningkat 6,647 poin). Sedangkan rata-rata kelompok kontrol hanya terjadi sedikit perubahan, yakni dari rata-rata 7,00 $(46,6 \%)$ menjadi $7,12(47,46)$ (ratarata meningkat 0,118 poin).

Dari analisis kuesioner pengetahuan responden pada saat pre test, item kuesioner yang paling banyak tidak diketahui oleh responden adalah kuesioner nomor 5 yaitu sebanyak 76,5\% responden kelompok intervensi (13 orang) dan $64,7 \%$ responden kelompok kontrol (11 orang) memberikan jawaban stimulasi perkembangan dapat diberikan sewaktu-waktu saja.

Dari analisis kuesioner post test yang dilakukan oleh peneliti pada kelompok intervensi dan kelompok kontrol, peneliti menemukan adanya perbaikan jawaban tentang waktu pemberian stimulasi. Pada kelompok intervensi seluruh responden telah menjawab dengan tepat hingga mencapai $100 \%$ (17 orang). Sedangkan pada kelompok kontrol hanya $41,0 \%$ (7 orang) yang menjawab benar. Hal ini menunjukkan bahwa pendidikan kesehatan yang dilakukan peneliti telah dapat meningkatkan pengetahuan responden kelompok intervensi tentang stimulasi perkembangan anak khususnya tentang waktu pemberian stimulasi.

Hasil penelitan ini sejalan dengan penelitian Antriana \& Suyanti (2019) menyatakan bahwa nilai ratarata post test pengetahuan responden meningkat, yakni $84,63(70,52 \%)$ (dari total skor 120). Selanjutnya penelitian Cumayunaro (2020) juga menemukan bahwa rata-rata post test pengetahuan meningkat, yakni 14,53 $(51,89 \%)$ (dari total skor 28). Kemudian Latifah \& Andriani (2018) juga menemukan hasil bahwa skor pengetahuan ibu meningkat, yaitu $70,86(64,41 \%)$ (dari total skor 110).

Stimulasi adalah rangsangan yang datangnya dari lingkungan baik itu dari lingkungan keluarga maupun lingkungan masyarakat yang diberikan setiap saat dan bukan hanya waktu tertentu saja (Iva, 2010). Pemberian stimulasi yang bervariasi secara teratur dan terus menerus akan menciptakan balita yang cerdas, tumbuh kembang yang optimal, mandiri serta memiliki emosi yang stabil dan mudah beradaptasi(Soetjiningsih, 2017). Oleh karena itu, dikarenakan anak usia pra sekolah merupakan periode emas dan merupakan saat yang tepat untuk mengoptimalkan perkembangan anak, maka ibu sangat diharuskan untuk memahami bentuk rangsangan atau stimulasi yang sesuai agar potensi anak berkembang dengan baik dan sempurna.

Menurut asumsi peneliti, berdasarkan analisis kuesioner, ketidaktahuan responden tentang kapan anak diberikan stimulasi perkembangan dapat dikaitkan dengan karakteristik pendidikan responden, yakni hanya 11,8 kelompok intervensi dan $88,2 \%$ dan hanya 17,6 kelompok kontrol yang berpendidikan perguruan tinggi.

Menurut Fitriani (2015) pendidikan merupakan suatu kegiatan bimbingan yang diberikan kepada sesorang terhadap agar dapat dipahami dan meningkatkan keilmuannya. Semakin tinggi pendidikan seseorang, maka akan semakin mudah mencerna dan menerima informasi yang diberikan sehingga semakin banyak keilmuan yang didapatkannya. Sedangkan pada orang yang memiliki tingkat pendidikan rendah, maka akan lebih sulit untuk menerima informasi dan akan menghambat perkembangan pengetahuannya terhadap penerimaan informasi serta nilai baru yang disampaikan padanya.

Menurut Hati \& Lestari (2016) seorang anak memerlukan perhatian khusus untuk optimalisasi tumbuh kembangnya. Optimalisasi perkembangan diperlukan adanya interaksi antara anak dan orangtua, terutama peranan ibu sangat bermanfaat bagi proses perkembangan anak secara keseluruhan karena orangtua dapat segera mengenali kelainan proses perkembangan anaknya sedini mungkin dan memberikan stimulus tumbuh kembang anak yang menyeluruh dalam aspek fisik, mental dan sosial.

Pada masa ini usia prasekolah terjadi tranformasi yang pesat pada otak dan fisik pada anak sekaligus masa yang harus diperhatikan, oleh karena itu masa ini sangat penting bagi perkembangan intelektual, emosidan sosial (Sedayu, 2016). Oleh karena itu penting bagi ibu untuk mengetahui hal ini agar perkembangan anak tidak terhambat.

Berdasarkan hasil penelitian yang sudah didapatkan, maka untuk mendapatkan hasil yang maksimal terkait perkembangan anak dari aspek fisik, mental dan sosial maka peneliti berharap pada seluruh ibu yang memiliki anak usia prasekolah untuk mau meningkatkan pengetahuannya tentang stimulasi yang harus diberikan pada anak sesuai dengan usianya

\section{Sikap}

Berdasarkan hasil penelitian yang sudah dilakukan peneliti tentang rata-rata sikap sebelum dan 
setelah diberikan intervensi (pada kelompok intervensi dan kelompok kontrol) didapati hasil rata-rata pre test sikap kelompok intervensi adalah 28,06 (56,12\%) (dari total skor 50). Selanjutnya rata-rata pre test sikap kelompok kontrol adalah 27,94 (55,88\%) (dari total skor 50). Hasil penelitian ini menunjukkan bahwa ratarata pre test sikap kedua kelompok masih perlu ditingkatkan.

Hasil penelitan ini sejalan dengan penelitian Cumayunaro (2020) menyatakan bahwa nilai rata-rata pre test sikap responden masih rendah yakni 49,24 $(55,35 \%)$ (dari total skor 90). Selanjutnya penelitian Nurjanah (2015) juga menemukan bahwa rata-rata pre test sikap yang masih kurang baik $(76,45)(50,96 \%)$ (dari total skor 150). Kemudian Nurwegha \& Prayogi (2014) juga menemukan hasil bahwa skor pre test sikap ibu 70,0 (53,84\%) (dari total skor 130).

Setelah diberikan pendidikan kesehatan degan media booklet (post test), rata-rata sikap ibu tentang stimulasi perkembangan anak usia prasekolah pada kelompok intervensi telah mengalami peningkatan, yakni dari 28,06 (56,12\%) menjadi 45,59 (91,18\%) (rata-rata meningkat 17,52 poin). Sedangkan rata-rata kelompok kontrol hanya terjadi sedikit perubahan, yakni dari rata-rata 27,94 $(55,88 \%)$ menjadi $28,12(56,24 \%)$ (rata-rata meningkat 0,175 poin).

Dari analisis kuesioner sikap responden pada saat pre test, item kuesioner yang paling rendah adalah kuesioner nomor 4, yaitu sebanyak $82,4 \%$ responden kelompok intervensi (14 orang) dan 88,2\% responden kelompok kontrol (15 orang) memberikanjawaban "setuju" stimulasi perkembangan dapat diberikan sewaktu-waktusaja.

Dari analisis kuesioner post test yang dilakukan oleh peneliti, peneliti menemukan adanya perbaikan jawaban sikap item kuesioner nomor 4. Pada kelompok intervensi, jawaban responden mencapai $94,1 \%$ (16 orang) yang menjawab "sangat tidak setuju" dengan pernyataan tentang stimulasi perkembangan dapat diberikan sewaktu-waktu saja. Hal ini menunjukkan bahwa pendidikan kesehatan yang dilakukan peneliti telah dapat mampu memperbaiki sikap responden.

Hasil penelitan ini sejalan dengan penelitian Cumayunaro (2020) menyatakan bahwa nilai rata-rata post test sikap responden meningkat yakni 50,37 $(55,96 \%)$ (dari total skor 90).. Selanjutnya penelitian Nurjanah (2015) juga menemukan bahwa rata-rata post test sikap mengalami perbaikan yaitu $86,5(57,66 \%)$ (dari total skor 150).

Menurut peneliti, sikap negatif dari ibu yang beranggapan semua anak akan mencapai kemampuan perkembangannya sendiri seiring dengan bertambahnya usia adalah dikarenakan ibu belum memahami apa saja bentuk dari perkembangan anak dan cara yang dapat dilakukan untuk memaksimalkan perkembangan anak.

Menurut Dwienda (2014), untuk memaksimalkan perkembangan anakdan seluruh potensi yang telah dimilikinya juga berkembang secara optimal, maka dibutuhkan upaya-upaya dari lingkungan eksternal seperti masyarakat serta semangat dari faktor internal seperti dari keluarga sehingga anakdapat menghadapi kompetisi pada fase berikutnya (remaja, dewasa, tua dan lansia). Karena kesuksesan perkembangan di usia dini akan menentukan kesuksesan perkembangan selanjutnya. Hal ini sangat dipengaruhi oleh sikap orang tua terutama ibu terhadap kondisi perkembangan anaknya.

Sikap merupakan reaksi yang masih tertutup dari seseorang terhadap stimulus. Sikap belum merupakan suatu tindakan nyata, tetapi masih berupa persepsi dan kesiapan seseorang untuk bereaksi terhadap stimulus yang ada di sekitarnya. Sikap dapat diukur secara langsung dan tidak langsung (Notoatmodjo, 2012a).

Sikap ibu tentang stimulasi perkembangan pada anak sangat penting. Menurut Wijayanti \& Edmiandini (2015), sikap ibu dalam memberikan stimulasi perkembangan hendaknya lebih di perhatikan lagi. Sebab stimulasi harus sering dilakukan untuk merangsang kemampuan anak dalam tahap perkembangannya.

Perkembangan (development) adalah bertambahnya kemampuan atau keahlian dalam struktur dan fungsi tubuh yang lebih kompleks, dalam pola yang teratur, sebagai hasil dari proses pematangan. Perlu diingat bahwa pertumbuhan dan perkembangan setiap individu bersifat unik. Hal ini disebabkan oleh beberapa faktor diantaranya faktor genetik (faktor bawaan), lingkungan (baik itu biologis ataupun psikologis) dan perilaku (keadaan/perilaku pada keluarga) (Rihlah, 2019). Oleh sebab itu, menurut asumsi peneliti, anak tidak seharusnya berkembang dengan sendirinya melainkan sangat membutuhkan bantuan untuk mencapai perkembangan yang maksimal.

Menurut Sukamti \& Fauziah (2014), perkembangan adalah bertambahnya struktur dan fungsi tubuh yang lebih kompleks dalam kemampuan gerak kasar, gerak halus, bicara dan bahasa serta sosialisasi dan kemandirian. Kegiatan stimulasi adalah merangsang anak usia 0-6 tahun agar tumbuh dan berkembang secara optimal. Stimulasi ini dapat dilakukanoleh orang tua seperti ayah atau ibu, pengasuh ataupun anggota keluarga lain dalam kehidupan anak sehari hari sesuai usianya sehingga didapatkan anak yang berkualitas.

Menurut asumsi peneliti, kegiatan stimulasi tidak akan dapat berjalan dengan baik selama ibu tidak memperbaiki sikapnya. Sikap yang positif mengenai suatu hal akan mendorong individu untuk berperilaku sesuai dengan yang diyakininya. Oleh sebab itu agar seluruh responden memiliki sikap yang postif tentang stimulasi perkembangan pada anak usia sekolah, maka peneliti menyarankan kepada perawat di Puskesmas Lubuk Buaya agar dapat memberikan edukasi tentang pentingnya stimulasi untuk mengoptimalkan perkembangan anak. 
Melda Saputri et al., Pengaruh Pendidikan Kesehatan dengan Media Booklet Terhadap Pengetahuan, Sikap dan Tindakan Ibu Tentang Stimulasi Perkembangan Anak Usia Pra Sekolah di Wilayah Kerja Puskesmas Lubuk Buaya Kota Padang

\section{Tindakan}

Berdasarkan hasil penelitian yang sudah dilakukan peneliti tentang rata-rata tindakan ibu tentang stimulasi perkembangan anak usia prasekolah sebelum dan setelah diberikan intervensi (pada kelompok intervensi dan kelompok kontrol) didapati hasil rata-rata pre test tindakan ibu kelompok intervensi adalah 14,35 $(57,40 \%)$ (dari total skor 25$)$. Selanjutnya rata-rata pretest tindakan ibu kelompok kontrol adalah 14,29 $(57,16 \%)$ (dari total skor 25$)$. Hasil penelitian ini menunjukkan bahwa rata-rata pre test tindakan kedua kelompok masih perlu ditingkatkan.

Hasil penelitan ini sejalan dengan penelitian Ina \& Betan (2017) menyatakan bahwa nilai rata-rata pre test tindakan responden masih rendah yakni 18,8 (53,71\%) (dari total skor 35).

Setelah diberikan pendidikan kesehatan degan media booklet (post test) rata-rata tindakan ibu tentang stimulasi perkembangan anak usia prasekolah pada kelompok intervensi telah mengalami peningkatan, yakni dari $14,35(57,40 \%)$ menjadi $22,59(90,36 \%)$ (rata-rata meningkat 8,235 poin). Sedangkan rata-rata kelompok kontrol hanya terjadi sedikit perubahan, yakni dari rata-rata $14,29(57,16 \%)$ menjadi $14,41(57,65 \%)$ (rata-rata meningkat 0,118 poin).

Dari analisis kuesioner tindakan responden pada saat pre test, pada kelompok intervensi dari 25 item tindakan stimulasi ibu yang memiliki anak usia 3-4 tahun, item tindakan yang paling banyak tidak dilakukan adalah adalah $66,7 \%$ ibu tidak melibatkan anak ketika memasak dengan memberi kesempatan anak membubuhkan sesuatu atau mengaduk, pada kelompok kontrol didapatkan 66,7\% ibu tidak mengajarkan anak untuk memakaikan pakainnya sendiri dengan mengancingkan sendiri atau membuka dan menutup kancing.

Berdasarkan analisis kuesioner, pada responden dari 25 item tindakan stimulasi ibu yang memiliki anak usia 4-5 tahun, item tindakan yang paling banyak tidak dilakukan adalah adalah 62,5\% kelompok intervensi dan $87,5 \%$ kelompok kontrol tidak mengajarkan anak menggunting, menggunting kertas yang sudah dilipatlipat, membuat seperti rumbai-rumbai/orang/mobil.

Selanjutnya berdasarkan analisis kuesioner, pada kelompok intervensi dari 20 item tindakan stimulasi ibu yang memiliki anak usia 5-6 tahun, item tindakan yang paling banyak tidak dilakukan adalah adalah $100 \%$ kelompok intervensi dan $66.7 \%$ kelompok kontrol tidak mengajarkan anak menggunting, menggunting kertas yang sudah dilipat-lipat, membuat seperti rumbairumbai/orang/mobil.

Selanjutnya berdasarkan analisis kuesioner post test yang dilakukan oleh peneliti, peneliti menemukan adanya perbaikan tindakan ibu dalam stimulasi perkembangan anak. Pada kelompok intervensi, 100\% ibu mengajarkan anak untuk menggunting kertas yang dilipat, sedangkan kelompok kontrol baru mencapai 41
\%. Hal ini menunjukkan bahwa adanya perbaikan tindakan ibu dalam stimulasi perkembangan anak usia prasekolah. Hasil penelitan ini sejalan dengan penelitian Ina \& Betan (2017) menyatakan bahwa nilai rata-rata post test tindakan responden mengalami perbaikan, yakni $29,00(82,85 \%)$ (dari total skor 35$)$.

Berdasarkan analisis kuesioner yang dilakukan oleh peneliti, tidak dilakukannnya stimulasi oleh ibu dapat dikaitkan dengan karakteristik pekerjaan ibu, 76, $5 \%$ ibu sebagai wiraswasta, $11,8 \%$ PNS dan hanya $11,8 \%$ saja ibu yang tidak bekerja. Hal ini menyebabkan kurangnya waktu ibu dalam berinteraksi dengan anak sehingga Tindakan stimulasi perkembangan tidak dapat dilaksanakan secara maksimal.

Praktik/tindakan nyata adalah hal yang dilakuakn dari adanya suatu respon (Notoatmodjo, 2012a). Suatu tindakan yang dilakukan sesuai dengan urutan yang benar akan mampu melakukan suatu tindakan dengan sistematis, dari awal hingga akhir, akan menjadi kebiasaan dan pada akhirnya akan termodifikasi dengan baik. Pengukuran tindakan dapat dilakukan secara langsung dengan wawancara terhadap kegiatan-kegiatan yang telah dilakukan beberapa jam, hari atau bulan yang lalul (recall). Pengukuran juga dapat dilakukan secara langsung, yakni dengan mengobservasi tindakan atau kegiatan responden.

Menurut Kemenkes RI (2016) menggunting kertas yang dilipat merupakan suatu bentuk stimulasi yang dapat diberikan ibu pada anak usia 3-6 tahun. Hal ini dapat membantu anak mengembangkan kemampuan gerak halus. Motorik halus adalah aspek yang berhubungan dengan kemampuan anak melakukan gerakan yang melibatkan bagian-bagian tubuh tertentu yang dilakukan oleh otot-otot kecil, tetapi membutuhkan koordinasi yang cermat seperti mengamati sesuatu, menggambar, menggunting, menulis dan sebagainya.

Perkembangan motorik halus juga berpengaruh pada perkembangan kreativitas anak usia dini. Menurut Romlah (2017), perkembangan motorik adalah proses tumbuh kembang kemampuan gerak seorang anak. Latihan terhadap motorik halus perlu dilakukan guna meningkatkan kemampuan dalam melakukan dan mengendalikan gerakan tubuh dan anggotanya secara efektif, yang mencakup kegiatan untuk melatih koordinasi mata dan tangan, melatih konsentrasi, koordinasi indra dan anggota tubuh, melatih kepercayaan diri, keseimbangan tubuh, keberanian, kelenturan dan kekuatan otot. Dengan demikian maka perlu bagi ibu untuk melakukan semua stimulasi yang dapat mengembangkan motorik halus anak.

Stimulasi yang diberikan secara utuh dan berkisanambungan dapat memberikan banyak manfaat pada anak. Menurut Putra \& Misdiono (2018) stimulasi yang diberikan ibu dapat membuat anak merasa diperhatikan, dimengerti, disayangi, dihargai, membantu perkembangan emosi dan percaya diri, melatih mengemukakan pendapat atau masalah, 
mengembangkan keterampilan sosial, ekspresikan kreativitas bukan dengan kata-kata, dari pemalu menjadi asertif, pemusatan perhatian dan bekerjasama.

Menurut asumsi peneliti, dalam melaksanakan stimulasi pada anak, agar mendapatkan hasil yang maksimal, ibu tidak hanya fokus pada motorik halus saja, namun ibu juga harus dapat melaksanakan kegiatan stimulasi yang dapat meningkatkan kemampuan gerak kasar, berbicara, bahasadan kecerdasan, bergaul dan mandiri.

Berdasarkan penelitian yang sudah dilakukan, maka peneliti menyarankan pada perawat di Puskesmas Lubuk Buaya untuk dapat mendemonstrasikan seluruh bentuk stimulasi yang harus dilakukan ibu pada anaknya sehingga setiap anak yang berada di Puskesmas Lubuk Buaya mendapatkan manfaat dari stimulasi tersebut.

\section{Pengaruh Pendidikan Kesehatan terhadap Pengetahuan, Sikap dan Tindakan Ibu pada Kelompok Intervensi dan Kelompok Kontrol}

Berdasarkan hasil penelitian tentang pengaruh sebelum dan sesudah dilakukan pendidikan kesehatan terhadap pengetahuan, sikap dan tindakan ibu antara kelompok intervensi dan kelompok kontrol (pada kelompok intervensi dan kelompok kontrol) dengan menggunakan uji $\mathrm{T}$ Dependen didapati nilai $\mathrm{p}$ value kelompok intervensi untuk variabel pengetahuan $(\mathrm{p}=0,002)$, sikap $(\mathrm{p}=0,004)$ dan tindakan $(\mathrm{p}=0,006)$. Sedangkan nilai $\mathrm{p}$ value kelompok kontrol untuk variabel pengetahuan $(\mathrm{p}=0,163)$, sikap $(\mathrm{p}=0,083)$ dan tindakan $(\mathrm{p}=0,183)$. Hal ini dapat disimpulkan bahwa pendidikan kesehatan yang telah dilakukan memiliki pengaruh pada pengetahuan, sikap dan tindakan kelompok intervensi dan tidak ada pengaruh pada kelompok kontrol.

Hasil penelitian ini sejalan dengan penelitian yang telah dilakukan oleh Cumayunaro (2020) mendapatkan hasil bahwa adanya pengaruh pendidikan kesehatan yang diberikan terhadap pengetahuan $(\mathrm{p}=0,000)$, sikap ( $\mathrm{p}=0,005)$. Penelitian Hanim dkk (2019) mendapatkan adanya pengaruh pendidikan kesehatan terhadap pengetahuan $(\mathrm{p}=0,000)$ dan sikap $(\mathrm{p}=0,000)$. Penelitian Antriana \& Suyanti (2019) menemukan adanya pengaruh pendidikan kesehatan terhadap pengetahuan ibu $(\mathrm{p}=0,000)$, penelitian Ina \& Betan (2017) menemukan adanya pengaruh pendidikan kesehatan terhadap keterampilan ibu $(\mathrm{p}=0,000)$. Selanjutnya penelitian Alfianty dkk (2018) menemukan adanya pengaruh yang signifikan pendidikan kesehatan terhadap pengetahuan $(p=0,000)$ dan tidak ada pengaruhnya terhadap pengetahuan kelompok kontrol $(\mathrm{p}=0,414)$.

Pendidikan secara umum adalah segala upaya yang direncanakan untuk mempengaruhi pengetahuan, sikap dan tindakan orang lain, baik individu, kelompok atau masyarakat, sehingga mereka melakukan apa yang diharapkan oleh pelaku pendidikan, yang tersirat dalam pendidikan adalah: input adalah sasaran pendidikan (individu, kelompok, dan masyarakat), pendidik adalah (pelaku pendidikan), proses adalah (upaya yang direncanakan untuk mempengaruhi orang lain), output adalah (melakukan apa yang diharapkan atau perilaku) (Notoatmodjo, 2012). Kesehatan adalah keadaan sehat baik secara fisik, mental, spiritual, maupun sosial yang memungkinkan setiap orang untuk hidup produktif secara sosial dan ekonomi (Notoatmodjo, 2012)

Pendidikan kesehatan adalah aplikasi atau penerapan pendidikandalam bidang kesehatan. Secara operasional pendidikan kesehatan adalahsemua kegiatan untuk memberikan dan meningkatkan pengetahuanindividu, kelompok atau masyarakat dalam memeliharadanmeningkatkan kesehatan mereka sendiri (Notoatmodjo, 2012).

Pendidikan kesehatan yang dilakukan kepada kedua kelompok responden, hanya memiliki pengaruh yang signifikan terhadap pengetahuan, sikap dan tindakan pada kelompok intervensi saja dengan alpa < 0,05 . Hal ini dikarenakan responden kelompok intervensi mendapatkan perlakuan pendidikan kesehatan dengan media booklet, sedangkan responden kelompok kontrol hanya diberikan penyuluhan dengan metode ceramah tanpa diberikan booklet.

Booklet adalah buku berukuran kecil yang didesain untuk mendiskusikan pembaca dengan tips dan strategi untuk menyelesaikan masalah. Booklet biasanya terdiri dari 16-24 halaman dan berukuran 3,5×8,5 inchi. Booklet menjadi media yang cukup efektif untuk memberikan Pendidikan kesehatan pada ibu.(Cumayunaro, Ayuro., 2020).

Kelebihan media booklet yaitu dapat digunakan untuk belajar secara mandiri, pembaca dapat mempelajari isinya dengan santai, informasi dapat dibagikan dengan keluarga dan teman, mudah dibuat, diperbanyak dan diperbaiki serta mudah disesuaikan, dapat dibuat secara sederhana dengan biaya relative murah, awet dan dapat memuat banyak pesan, isi informasi media dapat diproduksi dengan ekonomis dan didistribusikan dengan mudah.

Menurut asumsi peneliti, adapun alasan dari adanya pengaruh yang signifikan terhadap pengetahuan, sikap dan tindakan ibu responden intervensiadalah dikarenakan booklet yang digunakan cukup sederhana dan mudah dimengerti oleh seluruh lapisan masyarakat, kemudian peneliti juga meminta ibu mengulang kembali dan membaca keseluruhan isi booklet yang diberikan sehingga ibu dapat mengingat materi booklet sehingga berdampak pada perubahan sikap dan terbentuk dalam perilakunya dalam melaksanakan stimulasi pada anaknya.

Berdasarkan hasil yang peneliti dapatkan maka diharapkan perawat yang ada di masayarakat dapat mengedukasi ibu mengenai stimulasi perkembangan anak dan diharapkan pula ibu mau menyediakan waktunya untuk membaca booklet dan melaksanakan 
Melda Saputri et al., Pengaruh Pendidikan Kesehatan dengan Media Booklet Terhadap Pengetahuan, Sikap dan Tindakan Ibu Tentang Stimulasi Perkembangan Anak Usia Pra Sekolah di Wilayah Kerja Puskesmas Lubuk Buaya Kota Padang

segala bentuk stimulasi pada anak sesuai dengan yang tercantum pada booklet.

\section{SIMPULAN}

1. Rata-rata pre test pengetahuan kelompok intervensi tentang stimulasi perkembangan anak usia prasekolah adalah 7,12 dan post test 13,76 . Rata-rata pre test pengetahuan kelompok kontrol tentang stimulasi perkembangan anak usia prasekolah adalah 7,00 dan post test 7,12.

2. Rata-rata pre test sikap kelompok intervensi tentang stimulasi perkembangan anak usia prasekolah adalah 28,06 dan post test 45,59. Ratarata pre test sikap kelompok kontrol tentang stimulasi perkembangan anak usia prasekolah adalah 27,94 dan post test 28,12.

3. Rata-rata pre test tindakan kelompok intervensi tentang stimulasi perkembangan anak usia prasekolah adalah 14,35 dan post test 22,59. Ratarata pre test tindakan kelompok kontrol tentang stimulasi perkembangan anak usia prasekolah adalah 14,29 dan post test 14,41 .

4. Ada pengaruh pendidikan kesehatan terhadap pengetahuan $(p=0,002)$, sikap $(p=0,004)$ dan tindakan $(\mathrm{p}=0,006)$ pada kelompok intervensi. Selanjutnya tidak ada pengaruh pendidikan kesehatan terhadap pengetahuan $(\mathrm{p}=0,163)$, sikap $(\mathrm{p}=0,083)$ dan tindakan $(\mathrm{p}=0,183)$ pada kelompok kontrol.

\section{DAFTAR PUSTAKA}

Alfianty, U., Sulistiyawati., \& Santoso. (2018). Pengaruh Pemberian Edukasi tentang Stimulasi Tumbuh Kembang balita terhadap Pengetahuan Ibu di Community Feeding Center di Wilayah Kerja Puskesmas Sedayu. Jurnal Universitas Alma Ata. Yogyakarta. 1-15

Antriana, I. \& Suyanti (2019). Pengaruh Pendidikan Kesehatan terhadap Pengetahuan Ibu Pra Sekolah tentang Stimulasi Perkembangan Anak di Wilayah Kerja UPTD Puskesmas Banjaran Kabupaten Majalengka. Jurnal STIKES YPIB Majalengka. 8(16), 49-56

Azwar, S. (2013). Sikap Manusia: Teori dan Pengukurannya. Yogyakarta. Pustaka Pelajar.

Cumayunaro, Ayuro., D. (2020). Pendidikan Kesehatan dengan Media Booklet Terhadap Perilaku Ibu dalam Melakukan Deteksi Dini Tumbuh Kembang ( DDTK ) pada Anak. 16(1), 18-26.

Depkes., R. (2016). Pedoman pelaksanaan stimulasi, deteksi, dan intervensi tumbuh kembang anak.

Dinkes. (2020). Laporan tahunan tahun 2019 edisi 2020 1. Dinas Kesehatan Kota Padang.

Dwienda, R., Octa, \& Dkk. (2014). Buku Ajar Asuhan Kebidanan Neonatus, Bayi/Balita dan Anak Prasekolah. CV Budi Utama.

Fadlyana, E., Alisjahbana, A., Nelwan, I., Noor, M.,
Selly, S., \& Sofiatin, Y.(2016). Pola Keterlambatan Perkembangan Balita di daerah Pedesaan dan Perkotaan Bandung, serta Faktorfaktor yang Mempengaruhinya. Sari Pediatri, 4(4), 168. https://doi.org/10.14238/sp4.4.2003.168-75

Fitriani, M. (2015). Promosi Kesehatan Komunitas. Rineka Cipta

Hanim, H., Ristia, A., \& Hidayati. (2019). Pengaruh Pendidikan Kesehatan terhadap Pengetahuan dan Sikap Ibu tentang Deteksi Dini Tumbuh Kembang Balita di Desa Gampong Jawa Kecamatan Langsa. Jurnal Pendidikan dan Praktik Kesehatan. 3(2), 214-228

Hati \& Lestari (2016). Tumbuh Kembang Anak. Rineka Cipta. Jakarta

Ina, A., \& Betan, M.O. (2017). Pengaruh Pendidikan Kesehatan Tentang Deteksi Dini Perkembangan Anak Usia Balita Terhadap Peningkatan Pengetahuan dan Ketrampilan Ibu Dalam Melakukan Deteksi Dini Perkembangan Anak di Pusat Kesehatan Masyarakat Sikumana, Kota Kupang. Jurnal Info Kesehatan. 15(1), 1-13

Kusuma, I. F., \& dkk. (2013). Hubungan pengetahuan ibu tentang stimulasi dini dengan perkembangan motorik pada anak usia 6-24 bulan di kecamatan mayang kabupaten jember. Ikesma, 9(1), 2

Latifah, N.S., \& Andriani, T. (2018). Pengaruh Penyuluhan Kesehatan terhadap Pengetahuan Ibu tentang Stimulasi Perkembangan Balita Usia 3-5 Tahun di Posyandu Sakura Kelurahan Gunung Mas Teluk Betung Selatan Lampung. Jurnal Kebidanan. 4(2), 90-96

Noorlaila Iva. (2010). Panduan Lengkap Mengajar Paud. Pinus Book.

Notoadmodjo, S. (2012). Metodologi Penelitian Kesehatan. Rineka Cipta.

Notoatmodjo, S. (2012a). Metodologi Penelitian Kesehatan. Rineka Cipta.

Nurjanah, N. (2015). Pengaruh penkes stimulasi perkembangan anak terhadap pengetahuan dan sikap orangtua di rumah bintang islamic pre school. Jurnal Ilmu Keperawatan, III(2), 112119.

Putra, A. Y., Yudiemawat, A., \& Maemunah, N. (2018). Pengaruh Pemberian Stimulasi Oleh Orang Tua Terhadap Perkembangan Bahasa Pada Anak Usia Toddler Di Paud Asparaga Malang. Nursing News, 3(1), 563-571.

Rihlah, E. (2019). Gangguan Perkembangan pada Anak. Jakarta. EGC.

Romlah, Y. (2017). Anak Sehat Kebanggan Keluarga. Jakarta. EGC.

Sedayu, K. (2016). Pengaruh Pemberian Stimulasi pada Perkembangan Anak Usia 12-36 The In fl uence of Stimulation in Children Aged 12-36 Months in Sedayu Regency, Bantul. Journal Ners And 
Midwifery Indonesia, 4(1), 44-48.

Soetjiningsih. (2017). Tumbuh Kebang Anak, edisi 2 (2nd ed.). EGC.

Sukamti, S. \& Fauziah, A. (2014). Stimulasi Dini Pada Pola Asuh Berdampak Positif Terhadap Perkembangan Anak Bawah Dua Tahun. Jurnal Ilmu dan Teknologi Kesehatan. Jakarta

Syahailatua, J., \& Kartini, K. (2020). Pengetahuan ibu tentang tumbuh kembang berhubungan dengan perkembangan anak usia 1-3 tahun. Jurnal Biomedika Dan Kesehatan, 3(2), 77-83. https://doi.org/10.18051/jbiomedkes.2020.v3.7783

Syofiah, P. N., Machmud, R., \& Yantri, E. (2019). Analisis Intervensi Pelaksanaan Dini Program Deteksi Balita dan di Tumbuh Kembang ( SDIDTK ) Puskesmas Kota Padang Tahun 2018. Jurnal Kesehatan Andalas, 8(4), 151-156.

UNICEF. (2017). Laporan Baseline SDG tentang AnakAnak di Indonesia. Kementerian Perencanaan Pembangunan Nasional (Bappenas) Dan United Nations Children's Fund, 1-105. https://www.unicef.org/indonesia/id/SDG_Baselin e_report.pdf

Wijayanti, A. R., \& Edmiandini, U. F. (2017). Hubungan Sikap Ibu Tentang Stimulasi Perkembangan Dengan Tahap Perkembangan Motorik Kasar Pada Anak Usia 3-4 Tahun. Jurnal Kebidanan, 10, 88.

Yopy, B., Nurwegha, F., \& Prayogi, B. (2014). Pengaruh Pendidikan Kesehatan Tentang Stimulasi Perkembangan Anak Usia 0-3 Tahun Terhadap Pengetahuan Dan Sikap Orang Tua. Jurnal Ners Dan Kebidanan, 1(1). https://doi.org/10.26699/jnk.v1i1.ART.p013-018 